\title{
NOTES ON PETROGRAPHY AND ROCK-FORMING MINERALOGY (11) \\ GREEN BIOTITE IN SANBAGAWA BASIC SCHISTS IN THE KANTO MOUNTAINS, JAPAN
}

\author{
Chiniro SakaI
}

\begin{abstract}
Department of Earth Sciences, Kanazawa University, Kanazawa 920
In the northeastern part of the Kanto Mountains, central Japan, in basic schists, green biotite widely occurs in a lower-grade part where garnet is common in pelitic and psammitic schists, while brown biotite is present in a higher-grade part where brown biotite commonly occurs in them.

Comparing with brown biotite from higher-grade part of the Sanbagawa metamorphic terrain in this area and central Shioku, green biotite in lower-grade part of this area contains lower $\mathrm{Al}_{2} \mathrm{O}_{3}$ and higher $\mathrm{Fe}_{2} \mathrm{O}_{3}$, and slightly lower $\mathrm{TiO}_{2}$.

On the basis of the paragenetic relation of the green biotite-bearing assemblages, the occurrence of green biotite is explained by high $\mathrm{Fe}_{2} \mathrm{O}_{3}$, ( $\mathrm{FeO}+\mathrm{MgO}$ ), and low $\mathrm{Al}_{2} \mathrm{O}_{3}$ contents of the host rocks. Brown biotite in basic schists in a higher-grade part is formed by the following reaction;

green biotite $+(\mathrm{Fe}, \mathrm{Mg}$-rich) chlorite + epidote + albite +quartz = brown bitite + hornblende + (Al-rich)chlorite + magnetite $+\mathrm{H}_{2} \mathrm{O}$.

This reaction enlarges the stability field of biotite, and in a higher-grade part, brown biotite-bearing assemblages widely occurs in the common basic schists.
\end{abstract}

\section{INTRODUGTION}

Green biotite widely occurs in the lowgrade basic schists of the Sanbagawa metamorphic terrain in the Kanto Mountains (Tanaka and Fukuda, 1974; Toriumi, 1975; Suzuki, 1977; Sakai, 1980). It occurs at the grade lower than the biotite zone where brown biotite occurs commonly in pelitic and psammitic sachists.

The paragenetic relation and chemistry of green biotite were studied in the eastern part of Onishi-machi, Gunma prefecture, to elucidate its stability field in relation to the chemical environments and physical conditions. The following intends to describe the mode of occurrence of green biotite along with discussing its genesis.

\section{MODE OF OGGURRENCE}

The study area is situated in the east of Onishi-machi, Gunma prefecture (Fig. 1). It can be divided into three metamorphic zones I, II and III that are defined by the paragenesis of pelitic and psammitic schists (Sakai, 1980). Zone I is the chlorite zone, zone II the garnet zone and zone III is the biotite zone in the sense of Higashino (1975). Green biotite occurs in basic schists in zone II and in a lower-grade part of zone III accompanied by chlorite, actinolite and epidote (Fig. 1 and Fig. 2). In a highergrade part of zone III, all biotites in basic schists are brown colored. 


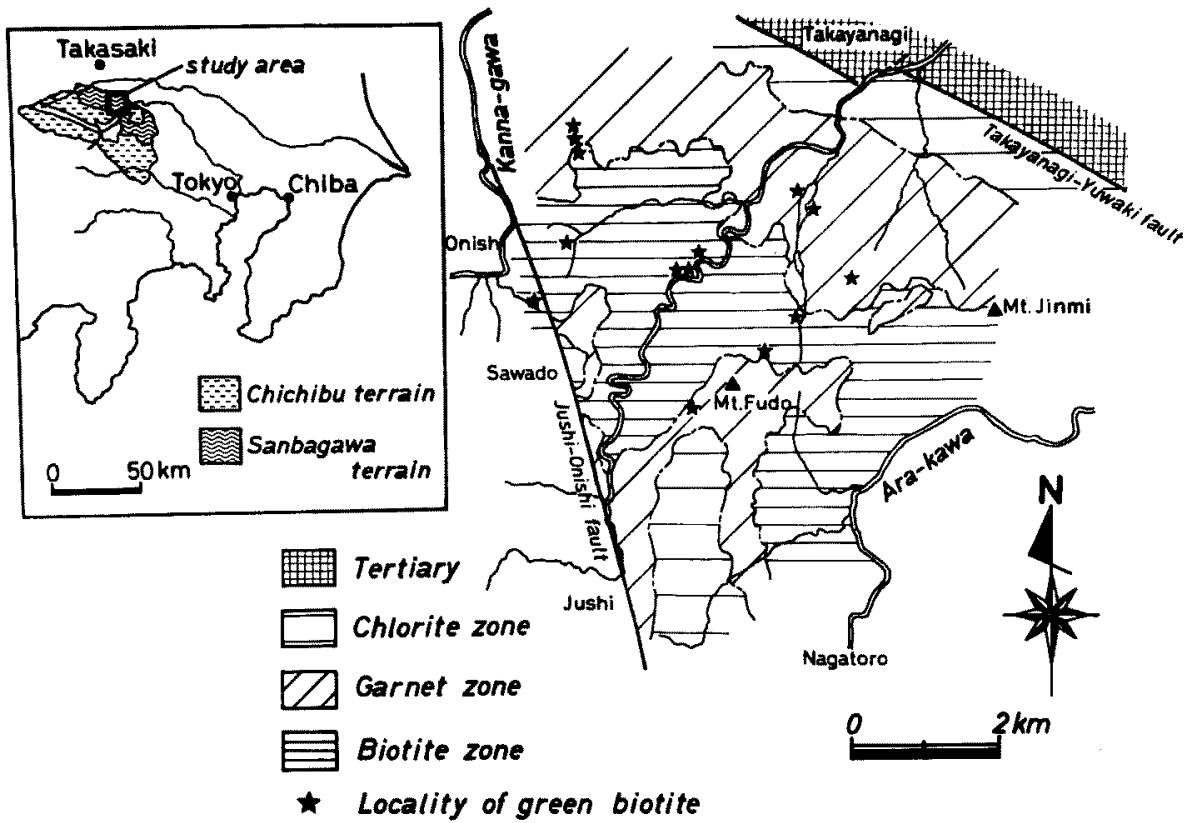

Fig. 1. Metamorphic zone map and sample localities of green biotite-bearing basic schists in the east of Onishi-machi, Kanto Mountains.

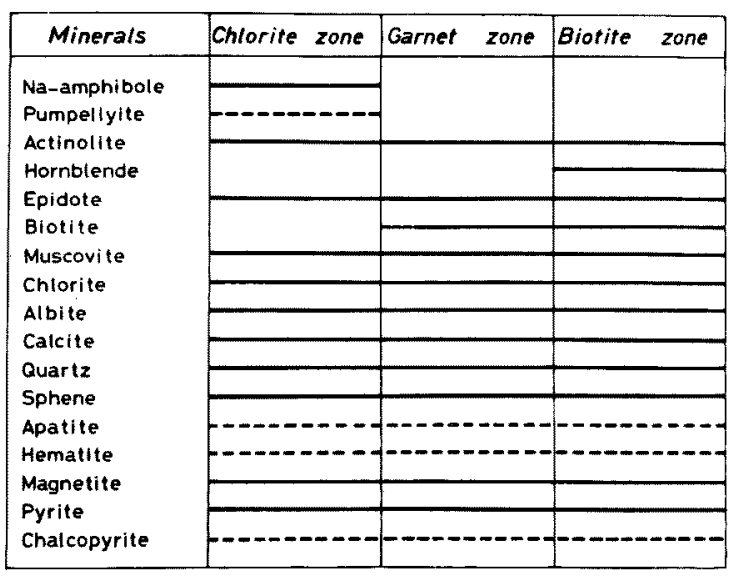

Fig. 2. Schematic stability of metamorphic minerals in basic schists in the study area.

In zone II, the mineral assemblages of the green biotite-bearing basic schists are as follows: quartz and albite are always associated, and accessory minerals are sphene, apatite, calcite, pyrite and chalcopyrite;

II-1) chlorite + actinolite + epidote + green biotite+magnetite,
II-2) chlorite + actinolite + epidote + green biotite + magnetite + hematite,

II-3) chlorite + actinolite + epidote + green biotite + muscovite.

The assemblage II-1 is the most common. The assemblages II-2 and II-3 are rare. Most of green biotites occur in contact with chlorite and muscovite, and their basal planes are elongated parallel to the schistosity plane, but in the magnetitebearing assemblages, some green biotites are in contact with euhedral magnetite.

The optical properties of the green biotite in zone II are as follows:

axial color $\mathrm{X}=$ colorless-pale yellow, $\mathrm{Y}=\mathrm{Z}$ $=$ dark green; refractive index $\beta=1.636 \pm$ 0.001 ; otpical angle $2 \mathrm{~V}_{\mathrm{X}} \fallingdotseq 0^{\circ}$.

In a lower-grade part of zone III, the mineral assemblages of the green biotitebearing basic schists are as follows: again quartz and albite are always present, and accessory minerals are sphene, apatie, calcite, pyrite and chalcocpyrite. 
III-1) chlorite + actinolite + epidote + green biotite+magnetite,

III-2) chlorite + actinolite + epiodte + green biotite +hornblende,

III-3) chlorite+actinolite + epiodte + green biotite +muscovite,

III-4) chlorite + actinolite + epidote + green biotite + muscovite + hornblende,

III-5) chlorite+actinolite + epidote + green biotite + muscovite-magnetite.

The assemblages III-1 and III-2 are common. The assemblages III-3, III -4 and III $-\mathbf{5}$ are uncommon. Some of green biotites form the aggregates with muscovite and chlorite.

The optical properties of the green biotite in a lower-grade part of zone III are similar to those in zone II.

In a higher-grade part of zone III, green biotite is absent and brown biotitebearing assemblages are common. Brown biotite-bearing assemblages in a lower-grade and higher-grade part of zone III are as follows: quartz and albite are always associated, and the accessory minerals are similar to the green biotite-bearing assemblages.

lower-grade part of zone III:

III-6) chlorite + actinolite + epidote + brown biotite,

III-7) chlorite + actinolite + epidote + brown biotite + hornblende,

III-8) chlorite + actinolite + epidote + brown biotite + hornblende + magnetite,

III-9) chlorite + actinolite + epidote + brown biotite + hornblende + muscovite.

higher-grade part of zone III:

III-10) chlorite + actinolite + epidote + brown biotite + muscovite,

III-11) chlorite + actinolite + epidote + brown biotite + hornblende + muscovite.

\section{Ghemistry of Green BIOTIte}

The chemical composition of green biotite in a basic schist in a lower-grade part of zone III is shown in Table 1 . It was analyzed by the electron-probe microanalyzer, model JAX-5A of the Geological Survey of Japan following the procedure described by Okumura and Soya (1976). $\mathrm{Fe}_{2} \mathrm{O}_{3}$ and $\mathrm{FeO}$ were determined by the

Table 1. Chemical compositions of green biotite and chlorite in a basic schist from a lower-grade part of zone III (Sample No. CS78040513)

\begin{tabular}{|c|c|c|}
\hline Mineral & green biotite*** & chlorite**** \\
\hline $\mathrm{SiO}_{2}$ & 37.98 & 26.77 \\
\hline $\mathrm{TiO}_{2}$ & 1.33 & 0.07 \\
\hline $\mathrm{Al}_{2} \mathrm{O}_{3}$ & 16.48 & 21.21 \\
\hline $\mathrm{Fe}_{2} \mathrm{O}_{3}$ & 3.61 & \\
\hline Feo & 13.78 & 20.60 FeO $^{*}$ \\
\hline $\mathrm{MnO}$ & 0.20 & 0.28 \\
\hline Mgo & 13.63 & 20.59 \\
\hline Cao & 0.02 & 0.02 \\
\hline $\mathrm{K}_{2} \mathrm{O}$ & 9.74 & 0.08 \\
\hline $\mathrm{Na}_{2} \mathrm{O}$ & 0.12 & 0.05 \\
\hline $\mathrm{H}_{2} \mathrm{O}^{\star \star}$ & 4.03 & 12.39 \\
\hline Total & 100.92 & 102.06 \\
\hline $0=$ & 22.0 & 27.0 \\
\hline si & 5.589 & 5.185 \\
\hline $\mathrm{Ti}$ & 0.147 & 0.010 \\
\hline $\mathrm{Al}^{\mathrm{IV}}$ & 2.411 & 2.815 \\
\hline$A 1^{V I}$ & 0.447 & 2.027 \\
\hline $\mathrm{Fe}^{3+}$ & 0.399 & \\
\hline $\mathrm{Fe}^{2+}$ & 1.695 & 3.335 \\
\hline $\mathrm{Mn}$ & 0.025 & 0.045 \\
\hline Mg & 2.987 & 5.941 \\
\hline $\mathrm{Ca}$ & 0.005 & 0.005 \\
\hline $\mathrm{K}$ & 1.828 & 0.019 \\
\hline $\mathrm{Na}$ & 0.036 & 0.019 \\
\hline $\mathrm{OH}$ & 4.000 & 16.000 \\
\hline Total & 19.569 & 35.401 \\
\hline
\end{tabular}

FeO* means total iron as $\mathrm{FeO} . \mathrm{H}_{2} \mathrm{O} * *$ was determined by stoichiometry. green biotite*** is average of three grains. chlorite**** is average of two grains. 
wet chemical analysis in the Chiba University.

Suzuki (1977) described that green biotite is compositionally not different from brown biotite in the western part of the Kanto Mountains except for $\mathrm{MgO}$ and $\mathrm{Al}_{2} \mathrm{O}_{3}$ contents. However, the $\mathrm{TiO}_{2}$ content $(1.37 \mathrm{wt} \%)$ of green biotite in the study area and that $(1.32$ wt $\%)$ of Suzuki (1977) are slightly lower than that (1.28$2.06 \mathrm{wt} \%$ ) of brown biotite in the Sanbagawa schists in central Shikoku (Banno, 1964; Higashino, 1975). The $\mathrm{Al}_{2} \mathrm{O}_{3}$ contents of green biotites (Suzuki, 1977; this paper) are lower than those of the brown biotites from a higher-grade part in the respective terrain. The $\mathrm{Fe}_{2} \mathrm{O}_{3}$ content $(3.61 \mathrm{wt} \%)$ of green biotite is higher than that $(0.27-1.07$ wt $\%$ ) of brown biotites of biotite zone in central Shikoku except one sample, which contains 4.03 wt. per cent of $\mathrm{Fe}_{2} \mathrm{O}_{3}$ (Banno, 1964). Greenish tint of green biotite in the study area is due to high $\mathrm{Fe}_{2} \mathrm{O}_{3} /\left(\mathrm{Fe}_{2} \mathrm{O}_{3}+\mathrm{FeO}\right)$ ratio as shown by Hayama (1959).

\section{Phase Relation of Green Biotite- BEARING BASIC SCHISTS}

\section{Chemical system}

The chemical components necessary to describe the typical basic schists in the Sanbagawa metamorphic terrain are $\mathrm{SiO}_{2}$, $\mathrm{Al}_{2} \mathrm{O}_{3}, \mathrm{Fe}_{2} \mathrm{O}_{3}, \mathrm{FeO}, \mathrm{MgO}, \mathrm{CaO}, \mathrm{Na}_{2} \mathrm{O}, \mathrm{K}_{2} \mathrm{O}$ and $\mathrm{H}_{2} \mathrm{O}$. All green biotite-bearing basic schists contain quartz, albite and epidote, and then $\mathrm{SiO}_{2}, \mathrm{Ca}_{2.0} \mathrm{Al}_{2.6} \mathrm{Fe}^{3+}{ }_{0.4} \mathrm{Si}_{3} \mathrm{O}_{12}(\mathrm{OH})$ (average of $\mathrm{Fe}^{3+} /\left(\mathrm{Fe}^{3+}+\mathrm{Al}\right)$ in this area is $0.15)$, and $\mathrm{NaAlSi}_{3} \mathrm{O}_{8}$ can be regarded as excess components. Consequently, the mineral paragenesis of basic schists in the study area can be discussed in terms of five component system $\mathrm{Al}_{2} \mathrm{O}_{3}-\mathrm{Fe}_{2} \mathrm{O}_{3}-\mathrm{FeO}-\mathrm{MgO}$ $\mathrm{KAlSi}_{\mathbf{3}} \mathrm{O}_{8}$.

However, some essential features of the paragenetic relation may be revealed by treating it as a pseudo-quarternary system, in which $\mathrm{FeO}$ and $\mathrm{MgO}$ are jointly treated as if a single component. Fig. 3 shows the paragenetic relation of such a pseudoquarternary system with excess of quartz, albite and epidote.
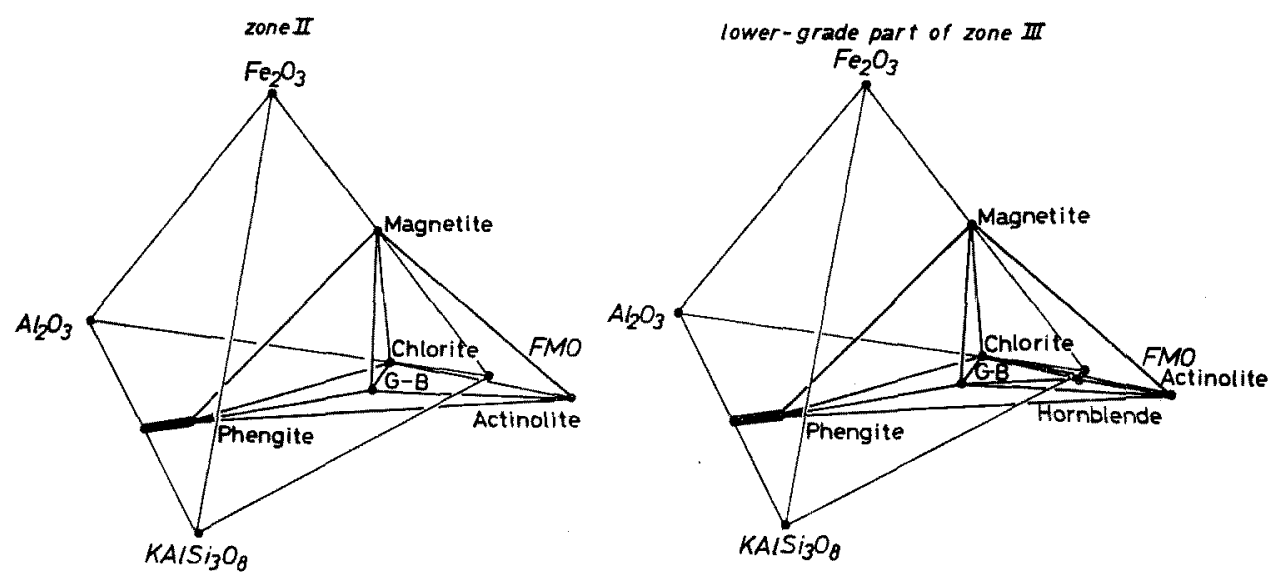

Fig. 3. Paragenetic relation in the pseudo-quarternary system $\mathrm{Fe}_{2} \mathrm{O}_{3}-\mathrm{Al}_{2} \mathrm{O}_{8}-(\mathrm{FeO}+\mathrm{MgO})-\mathrm{KAlSi}_{8} \mathrm{O}_{8}$ for the green biotite-bearing basic schists in zone II and a lower-grade part of zone III. Projection is made from quartz, albite, epidote and $\mathrm{H}_{2} \mathrm{O}$. FMO is ( $\mathrm{FeO}+\mathrm{MgO}$ ). G-B means green biotite. 
Here, the formulae for chlorite, green biotite and muscovite are assumed as follows:

$$
\begin{aligned}
& \text { chlorite }=\mathrm{Fe}^{2+}{ }_{5.9} \mathrm{Mg}_{3.3} \mathrm{Al}_{2.1}\left(\mathrm{Si}_{5.2} \mathrm{Al}_{2.8}\right) \\
& \left.\mathrm{O}_{19}(\mathrm{OH})_{16} \quad \text { (Table } 1\right) \text {, } \\
& \text { green biotite }=\mathrm{K}_{1.8}\left(\mathrm{Fe}^{2+}{ }_{1.7} \mathrm{Mg}_{3.0}\right) \\
& \left(\mathrm{Fe}^{3+}{ }_{0.4} \mathrm{Al}_{0.5}\right)\left(\mathrm{Si}_{5.5} \mathrm{Al}_{2.5}\right) \mathrm{O}_{20}(\mathrm{OH})_{4.0} \\
& \text { (Table 1), } \\
& \text { muscovite }=\mathrm{K}_{\mathbf{1 . 4}} \mathrm{Fe}^{2+}{ }_{\mathbf{0 . 2}} \mathrm{Mg}_{\mathbf{0 . 4}} \mathrm{Al}_{\mathbf{3 . 1}} \mathrm{Si}_{6.4} \mathrm{Al}_{\mathbf{1 . 6}} \\
& \mathrm{O}_{20}(\mathrm{OH})_{4.0} \quad \text { (Banno, 1964). }
\end{aligned}
$$

The maximum $\mathrm{Fe}_{2} \mathrm{O}_{3}$ content of chlorite from the Bessi district is $3.0 \mathrm{wt}$ per cent, then it may be ignored in crude treatment. The calciferous amphiboles such as actinolite and hornblende are plotted in the negative field in regard to the $\mathrm{Al}_{2} \mathrm{O}_{3}$ and $\mathrm{Fe}_{2} \mathrm{O}_{3}$ components.

Four-phase assemblages of green biotite-bearing basic schists

In Fig. 3, the following four-phase regions are distinguished. The parentheses show the observed assemblages of zone II and a lower-grade part of zone III.

1. chlorite + actinolite + green biotite + magnetite

2. chlorite + actinolite + green biotite + muscovite

(II-3 and III-3),

3. chlorite + hornblende + green biotite + magnetite

4. chlorite + actinolite + hornblende + green biotite

5. chlorite+green biotie + magnetite+ hematite,

6. chlorite+green biotite + muscovite + hematite,

7. actinolite + hornblende + green biotite + magnetite.

These mineral parageneses are compatible with the common mineral assemblages of other rock-types, such as phengite + chlorite + manganoan-garnet in pelitic and psammitic schists and chlorite+ actinolite (+epidote) in basic schists in zone II, and chlorite + hornblende (+epidote) in zone III.

Five-phase assemblages of green biotitebearing basic schists

The five-phase assemblages in the green biotite-bearing basic schists, such as the assemblages II-2, III-4 and III-5, can not be shown in Fig. 3. In the system where $\mathrm{FeO}$ and $\mathrm{MgO}$ are treated as independent components, however, they are compatible with the four-phase assemblages discussed above.

For example, green biotite-magnetitebearing five-phase assemblages, such as the assemblages II-2 and III- 5 are shown in a tetrahedral diagram, Fig. 4, where chlorite, green biotite, muscovite and hematite are projected from magnetite. The $\mathrm{FeO}$ component is plotted at minus infinite distance in this diagram. Green biotite, chlorite and actinolite are plotted in the negative field in regard to the $\mathrm{Fe}_{2} \mathrm{O}_{3}$ component. In this diagram, green biotite is also plotted in a tetrahedron of chlorite-actinolitemuscovite - hematite, and then the tetrahedron is divided into four volumes. Fig. 4 shows that the following four-phase volumes are distinguished.

1. green biotite + chlorite + actinolite + hematite (II-2),

2. green biotite + chlorite + actinolite + muscovite (III-5),

3. green biotite + chlorite + muscovite + hematite,

4. green biotite + actinolite + muscovite + hematite.

In this diagram, green biotite-magnetite-bearing four-phase assemblages II-1 and III-1 belong to these five-phase assemblages, and then these five-paragenetic relations are consistent with the assemblages 


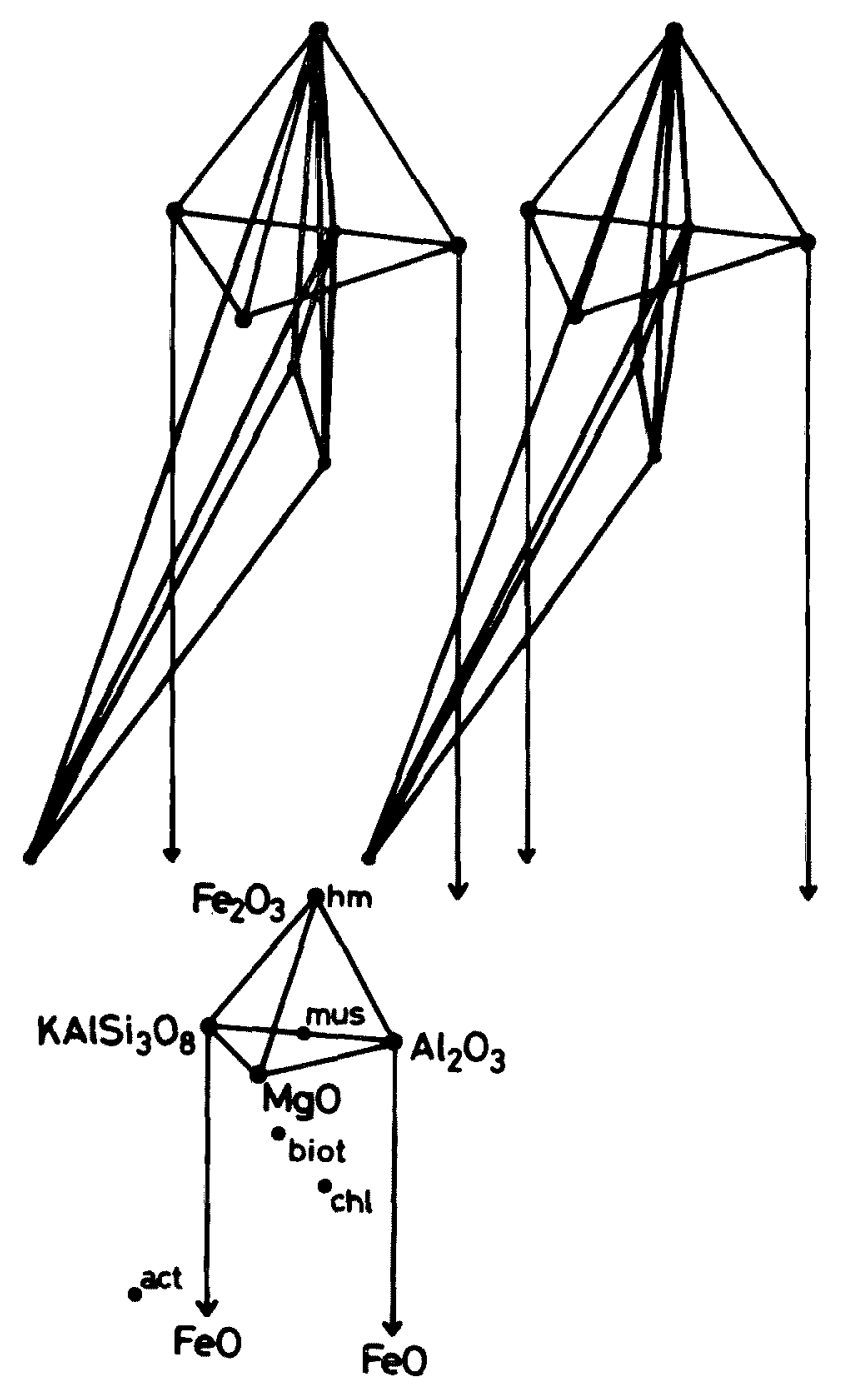

Fig. 4. Paragenetic relation of green biotite-bearing basic schists in zone II and a lower grade-part of zone III shown in the five-component system $\mathrm{Fe}_{2} \mathrm{O}_{3}-\mathrm{Al}_{2} \mathrm{O}_{3}-\mathrm{FeO}-\mathrm{MgO}-\mathrm{KAlSi}_{3} \mathrm{O}_{3}$ with exess magnetite. The projection points for actinolite, green biotite and chlorite are negative in regard to the $\mathrm{Fe}_{2} \mathrm{O}_{3}$ component. $\mathrm{FeO}$ component is plotted at minus infinite distance. "hm" = hematite; "mus"=muscovite; "biot"= green biotite; "chl" =chlorite; "act" = actinolite.

II-1 and III-1. Consequently, all the magnetite-bearing assemblages observed in the study area are compatible with each other.

The green biotite-muscovite-bearing five-phase assemblage, III-4, is also consistent with other green biotite-bearing assemblages in the quarternary system in which chlorite, actinolite, hornblende, green biotite, hematite and magnetite are projected from muscovite (Fig. 5). Fig. 5 shows the paragenetic relation of a quarternary $\mathrm{Fe}_{2} \mathrm{O}_{3}-\mathrm{Al}_{2} \mathrm{O}_{3}-\mathrm{FeO}-\mathrm{MgO}$ system with excess of quartz, albite, epidote and muscovite. Green biotite is plotted in the negative field in regard to the $\mathrm{Al}_{2} \mathrm{O}_{3}$ component. 


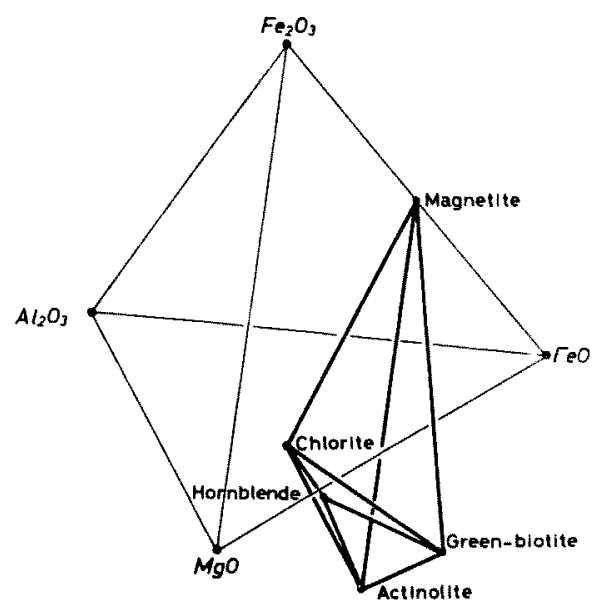

Fig. 5. Paragenetic relation for the green biotitemuscovite-bearing assemblages in the quarternary system $\mathrm{Fe}_{2} \mathrm{O}_{3}-\mathrm{Al}_{2} \mathrm{O}_{3}-\mathrm{FeO}-\mathrm{MgO}$. Projection is made from quartz, albite, epidote, muscovite and $\mathrm{H}_{2} \mathrm{O}$ as excess phases. The projection points for actinolite and hornblende are negative, for other minerals positive in regard to the $\mathrm{Fe}_{2} \mathrm{O}_{3}$ component.

Hornblende and actinolite are plotted in the negative field in regard to the $\mathrm{Al}_{2} \mathrm{O}_{3}$ and $\mathrm{Fe}_{2} \mathrm{O}_{3}$ components as well. The following mineral parageneses are distinguished from this diagram. The observed mineral parageneses in the green biotite-muscovite-bearing basic schists in the study area are shown in parentheses.

1. chlorite + actinolite + hornblende + green biotite (III-4),

2. chlorite+actinolite + magnetite + green biotite.

Green biotite-muscovite-bearing fourphase assemblages II- 3 and III-3 belong to five-phase assemblage III -4 , and then these green biotite-muscovite-bearing assemblages observed in the study area are compatibly shown in this diagram.

As a results, all the green biotite-bearing assemblages observed in the study area are compatible with each other.
Bulk composition of green biotite-bearing basic schists, and chemical reaction producing brown biotite

From Fig. 3, it is understood that green biotite occur in basic schists with relatively higher $\mathrm{Fe}_{2} \mathrm{O}_{3}$ and $(\mathrm{FeO}+\mathrm{MgO})$ contents and lower $\mathrm{Al}_{2} \mathrm{O}_{3}$ content than those of other rocktypes in zone II (garnet zone) and a lowergrade part of zone III (biotite zone), and that the mineral is absent from the pyrrhotite and carbonaceous matters-bearing common pelitic schists with low oxygen fugacity. As described previously, in a lower-grade part of zone III, some brown biotites occasionally occur in basic schists. They do not coexist with green biotite and the brown biotite-magnetite-bearing assemblage (III8 ) is uncommon. Therefore, brown biotite may occur in basic schists with lower $\mathrm{Fe}_{2} \mathrm{O}_{3}$ content than that of green biotite-bearing basic schists in a lower-grade part of zone III.

Green biotite disappears and brown biotite becomes more common in a highergrade part of zone III. As described previously, the $\mathrm{Al}_{2} \mathrm{O}_{3}$ content of brown biotite in a higher-grade part is higher, while the $\mathrm{Fe}_{2} \mathrm{O}_{3}$ content is lower than in green biotite. Mather (1970) has indicated that muscovite shows an increase in the amount of the $\mathrm{Al}_{2} \mathrm{O}_{3}$ component and a decrease in the $(\mathrm{FeO}+\mathrm{MgO})$ component as metamorphic grade increases in Dalradian. Ernst et al. (1970) and Otsuki (1980) have also shown that the $\mathrm{Al}_{2} \mathrm{O}_{3}$ content in chlorite and muscovite increases with increasing metamorphic temperature in the Sanbagwa metamorphic terrain. Consequently, in a higher-grade part of zone III, the formation of brown biotite may be explained by the following reaction;

green biotite $+(\mathrm{Fe}, \mathrm{Mg}$-rich) chlorite + epidote + albite + quartz (lower-grade 

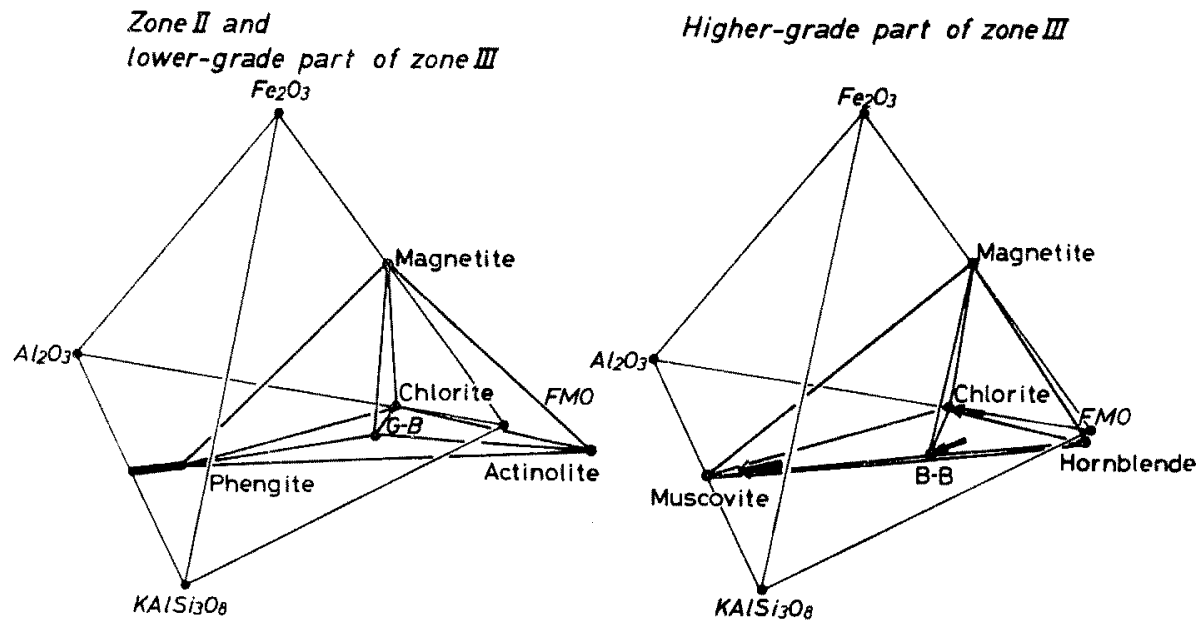

Fig. 6. $\mathrm{Fe}_{2} \mathrm{O}_{3}-\mathrm{Al}_{2} \mathrm{O}_{3}-(\mathrm{FeO}+\mathrm{MgO})-\mathrm{KAlSi}_{3} \mathrm{O}_{8}$ pseudo-quarternary diagram showing the enlargement of the stability field of the biotite-bearing assemblages with increasing metamorphic temperature. Projection points for actinolite and hornblende are negative in regard to the $\mathrm{Fe}_{2} \mathrm{O}_{3}$ component. $\mathrm{FMO}$ is $(\mathrm{FeO}+\mathrm{MgO}) . \quad \mathrm{G}-\mathrm{B}$ and $\mathrm{B}-\mathrm{B}$ denote green biotite and brown biotite, respectively.

part of zone III)

=brown biotite+hornblende + (Al-rich)

chlorite + magnetite $+\mathrm{H}_{2} \mathrm{O}$ (higher-grade

part of zone III).

Fig. 6 shows that the reaction enlarges the stability field of biotite in a higher-grade part of zone III. In this diagram, in a higher-grade part of zone III, the stability field of biotite in basic schists is larger than in a lower-grade part of zone III, and then brown biotite widely occurs in basic schists with relatively lower $\mathrm{Fe}_{2} \mathrm{O}_{3}$ and higher $\mathrm{Al}_{2} \mathrm{O}_{3}$ of the host rocks.

\section{Conclusions}

On the basis of the paragenetic relation of the biotite-bearing basic schists and chemical composition of the green biotite, the following conclusions are drawn. (1) Green biotite occurs in basic schists with relatively higher $\mathrm{Fe}_{2} \mathrm{O}_{3}$ and $(\mathrm{FeO}+\mathrm{MgO})$ contents and lower $\mathrm{Al}_{2} \mathrm{O}_{3}$ content. Therefore, it is absent from common pelitic schists with low oxygen fugacity in the Sanbagawa metamorpic terrain.
(2) Brown biotite in basic schists is formed by the following reaction;

green biotite $+(\mathrm{Fe}, \mathrm{Mg}$-rich) chlorite + epidote + albite + quart $z=$ brown biotite + hornblende + (Al-rich) chlorite + magnetite $+\mathrm{H}_{2} \mathrm{O}$.

The stability field of biotite-bearing assemblages enlarges with elevating temperature by this reaction. Consequently, brown biotite-bearing assemblages are more common in a higher-grade part, as we observed in field.

\section{AGKNOWLEDGEMENTS}

The author wishes to express my sincere thanks to Prof. S. Banno, Kyoto University, for his critical reading of this manuscript as well as his constructive critism and stimulating discussion. He would especially like to thank Prof. M. Yamazaki, Kanazawa University and Prof. K. Kanehira, Chiba University, for their critical reading. His thanks are also due to Mr. K. Takai, Chiba University, for the wet chemical analysis, and to Mr. T. Higashino, Hakusan 
Nature Conservation Center, for his kind advice and continuous encouragements. The electron-probe micro-analysis of green biotite and chlorite is carried out with EPMA of the Geological Survey of Japan by Mr. M. Imaizumi, now at Sumitomo Consultant Ltd. Thanks are also due to Mr. K. Okumura, Geological Survey of Japan, for the convenience of the micro-probe analysis.

\section{REFERENCE}

Banno, S. (1964), Petrologic studies on Sanbagawa crystalline schists in the Bessi-Ino district, central Sikoku, Japan. Jour. Fac. Sci. Univ. Tokyo, Sec II, 15, part 3, 203-319.

Ernst, W.G., Seki, Y., Onuki, H. and Gilbert, M.C. (1970), Comparative study of low-grade metamorphism in the California Coast Ranges and outer metamorphic belt of Japan. Geol. Soc. Am. Inc. Memoir 124, pp. 276.

Hayama, Y. (1959), Some considerations on the color of biotite and its relation to metamorphism. Jour. Geol. Soc. Japan, 65, 21-30.

Higashino, T. (1975), Biotite zone on Sanbagawa metamorphic terrain in the Siragayama area, central Sikoku, Japan. Jour. Geol. Soc. Japan, 81, 653-670 (in Japanese with English abstract).

Mather, J.D. (1970), The biotite isograd and the lower greenschist facies in the Dalradian rocks of Scotland. Jour. Petrol., 11, 253-275.

Okumura, K. and Soya, T. (1976), Quantitative analysis of silicate analysis by electron-probe microanalyzer. Jour. Mineral. Soc. Japan, 12, 116-124 (in Japanese with English abstract).

Otsuki, M. (1980), Petrological study of the basic Sanbagawa metamorphic rocks in central Shikoku, Japan. Ph. D. thesis, Univ. Tokyo.

Sakai, C. (1980), Biotite-zone in the Sambagawa metamorphic terrain east of Onishi-machi, Kanto Mountains. Jour. Geol. Soc. Japan, 86, 517-524 (in Japanese with English abstract).

Suzuki, M. (1977), On the Sambagawa metamorphic rocks of the western part in the Kanto Mountains, central Japan. in The Sambagawa Belt (Hide, K. ed.), Hiroshima Univ. Press, 207-216 (in Japanese with English abstract).

Tanaka, K. and Fulkuda, S. (1974), Geologic structure and metamorphic zoning of the northern extremity of the Sanbagawa metamorphic terrain in the Kanto Mountains - With special reference to the occurrence of biotites J. Japan. Assoc. Min. Petr. Econ. Geol., 69, 313-323 (in Japanese with Engish abstract).

Toriumi, M. (1975), Petrological study of the Sambagawa metamorphic rocks. Univ. Museum, Univ. Tokyo, Bull. 9, pp. 99.

\section{岩石学造岩鉱物学ノート(11) \\ 関東山地三波川塩基性片岩中の緑色黒雲母}

\section{酒 井千尋}

関東山地北東部に分布する三波川変成带のザクロ石帯から黒雲母帯の低温部では，塩基性片岩中に緑色黒雲母 が出現する。との緑色黑雲母の組成と，鉣物共生関倸を調べるととにより，その生成条件を考察した。 マイクロプローブと湿式の分析により，緑色黒雲母はより高変成度の岩石中に産する褐色黒雲母と比べて， $\mathrm{TiO}_{2}$ にわずかとそしく，比較的高い $\mathrm{Fe}_{2} \mathrm{O}_{3}$ 量と低い $\mathrm{Al}_{2} \mathrm{O}_{3}$ 量を含むととがわかった。とのととは，緑色黒雲母 の濃緑色の軸色が高い $\mathrm{Fe}_{2} \mathrm{O}_{3} /\left(\mathrm{Fe}_{2} \mathrm{O}_{3}+\mathrm{FeO}\right)$ 比任依存するとと示す。 $\mathrm{Fe}_{2} \mathrm{O}_{3}-\mathrm{Al}_{2} \mathrm{O}_{3}-(\mathrm{FeO}+\mathrm{MgO})-\mathrm{KAlSi}_{3} \mathrm{O}_{8}$

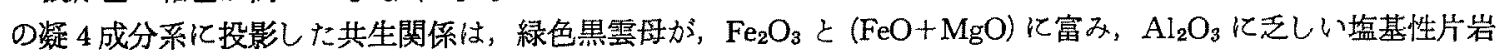
中に出現し, 普通の泥質片岩中には出現し得ないととを示す。より高温では, 緑色黒雲母+緑泥石十緑レン石十 曹長石十石英＝褐色黒雲母+ホルンブレンド十磁鉄鉱十緑泥石十水の反応が生し，黒雲母の安定領域が抎大され， 褐色黑雲母のみが出現する。

Onishi : 鬼石

Jushi : 出牛 